\title{
Plant soil seed bank analysis in wildfire former area of Mount Talang, West Sumatra, Indonesia
}

\author{
INDRA DWIPA", CHIKA SUMBARI, ASWALDI ANWAR \\ Department of Agronomy, Faculty of Agriculture, Universitas Andalas. Jl. Unand, Limau Manis Campus, Padang 25163, West Sumatra, Indonesia. \\ Tel./fax. +62-751-72701, `email: 1965indradwipa@gmail.com
}

Manuscript received: 21 August 2019. Revision accepted: 18 December 2019.

\begin{abstract}
Dwipa I, Sumbari C, Anwar A. 2020. Plant soil seed bank analysis in wildfire former area of Mount Talang, West Sumatra, Indonesia. Biodiversitas 21: 155-160. Forest wildfire affects the ecosystems that live in it. One of them is plant ecosystem. One of forest wildfire occurred in Mount Talang, West Sumatra, Indonesia on February 1, 2018. This research aimed to study the soil seed bank that grew after wildfire in mount Talang. The sampling collection was done from former forest fire and natural forest. Germination of soil seed bank was conducted in the Laboratory of Seed Technology, Faculty of Agriculture and identification was conducted in Herbarium of Department of Biology, Faculty of Mathematics and Natural Science, Andalas University, Padang, Indonesia. Nested sampling was used in this study. Two natural forest and 2 former forest wildfire sites were used as sampling locations. Observation plot for sampling collection sized as $2 \mathrm{~m} \mathrm{x} 2 \mathrm{~m}$ for sowing, $5 \mathrm{~m}$ x $5 \mathrm{~m}$ for stake, $10 \mathrm{~m} \times 10 \mathrm{~m}$ for pole and $20 \mathrm{~m}$ x $20 \mathrm{~m}$ for tree. In plot, soil seed bank sampling was taken in $0-5 \mathrm{~cm}, 5-10 \mathrm{~cm}, 10-15 \mathrm{~cm}$ and $15-20 \mathrm{~cm}$ in depth. The result showed that 1 family and 14 plant-soil seed bank species were found in natural forest and 8 plant-soil seed bank was found in forest wildfire former area.
\end{abstract}

Keywords: Forest fire, Mount Talang, natural forest, soil seed bank

\section{INTRODUCTION}

Indonesia is one of countries in the world that has mega-diversity, a country that has high flora diversity (Sutarno and Setyawan 2015). Indonesia is a center of biodiversity particularly of flora and is second place after Brazil (Rehulina et al. 2014). $25 \%$ of the world's biodiversity is in Indonesia. For each flora, it contains thousands of germplasm in unique combinations so that there are many genes in individuals of species (Kusmana and Hikmah 2015).

Forest is important natural resource of biodiversity as germplasm, seedling of natural vegetation, wood and nonwood forest product, soil water regulator, flood and erosion deterrent, biological protection for science interest, culture, recreation, and tourism (Puspitojati 2011). The disruption of natural resources continues even the intensity increases year to year.

West Sumatra is a region in Indonesia with $54,74 \%$ of this is still forest cover (Statistics West Sumatra 2018). One of forest areal in this province is Mount Talang. Mount Talang is active volcano in West Sumatra and it is located in Koto Anau, Solok District. The volcano altitude is 2.597 meter above sea level (m asl) (Center of Volcanology and Geological Hazard Mitigation 2018). The area is also called Mount Soelasih and it is type A strato active volcano formed by lava loop and pyroclastics (Welayaturrohman et al. 2013). On February 1, 2018, the fire forest occurred in this mountain area. The fire was started from top of volcano and spread to the south and east hillside.

Negative effect of this forest fire was appreciable, covered forest damage, increasing of biodiversity, loss of natural vegetation seeds, decreasing forest economic value and soil productivity. Syaufina et al. (2008) stated that effect of forest fire also caused micro and global climate change and the smoke disturbed human health and transportation (land, water, and air). Recently, disruption of tropical forest fire could cross neighborhood area.

According to the structure and composition, the forest wildfire affects the succession, a process cause the appearance of new vegetation and disappearance of existed vegetation. Bendixsen et al. (2016) stated that the forest that underwent wildfire naturally became secondary forest after underwent succession stages. Succession is an effort of an ecosystem to recover environmental biotic and abiotic components. The succession could be seen by the composition and structure of forest vegetation. Effect of forest fire covers all ecosystem aspects such as fauna, soil, water, climate, air, and human. Moreover, fire responded to decreasing plant species composition, alteration in quality and quantity of trees that are caused by heat. Due to heat of fire, plant metabolism process gets disturbed and plants undergo damage or even die. On the other side, forest encourages various adaptation of plant to heat such as germination, seed spreading and dormancy breakdown of certain seeds (Orozco 2017).

Seeds that undergo dormant are stored in soil depth and named seed bank. Fenner and Thompson (2005) stated that soil seed bank includes weed seeds storage or propagule. When growth factors become favorable possible, they developed to be a new individual. Santos et al. (2010) stated that the presence of seed bank in soil could be understood by the regrowth of new individual after forest fire occurred. Soil seed bank term is also called cluster of 
seed storage in soil and it can germinate when the environmental factor is appropriate and grow to produce seeds and they will be back into the soil as soil seed bank.

Seed bank plays an important role in regeneration in natural forest that undergoes fire. From structure and composition sides, forest fire affects the succession, appearance of new vegetation and loss of vegetation that existed before. Information about seed store in soil plays an important role in ecological studies of an ecosystem because it describes the vegetation and also potency of another plant species that grow in the habitat. The seed store in secondary forest is important as seeds source for plant colonization process in succession. According to the problems, a study of viable seed composition and soil seed banks is important in maintaining conservation in the Mount Talang area. The research aimed to study the effect of Mount Talang forest fire on soil seed bank and succession process.

\section{MATERIALS AND METHODS}

\section{Study area}

The research was conducted in former forest fire and natural forest of Mount Talang, Solok District, West Sumatra Province, Indonesia with altitude was $2.597 \mathrm{~m}$ asl. Soil seed bank analysis was conducted in the Laboratory of Seed Technology and identification was conducted in Herbarium of Faculty of Mathematics and Natural Sciences, Andalas University, Padang, West Sumatra, Indonesia from May to July 2018.

\section{Procedures}

Survey method was used for sampling in former forest wildfire and natural forest in Mount Talang area. Nested sampling, a method by using smaller plots was used in the assay (Fachrul 2012) (Figure 2). In each plot, subplots were made with size as follows : (i) Seedling. It was conducted from sprouts to $1.5 \mathrm{~m}$ in height such as ferns, bushes and herbaceous. The size of subplot was $2 \mathrm{~m} \times 2 \mathrm{~m}$. (ii) Sapling. It was started from $1.5 \mathrm{~m}$ of stem height and the diameter of stem was $10 \mathrm{~cm}$ such as non-wood, pandanus, and palm. The size of subplot was $5 \times 5 \mathrm{~m}$. (iii) Pole. Young trees that had $10-20 \mathrm{~cm}$ in diameter. The size of subplot was $10 \times 10 \mathrm{~m}$. (iv) Tree. Epiphytes and wood. The size of subplot was $0 \times 20 \mathrm{~m}$.

In natural forest area and former wildfire forest, 2 plots from each area were observed. For natural forest 1, the altitude was 2.529 asl, natural forest 2 , the altitude was $2.524 \mathrm{~m}$ asl. For former wildfire forest 1, the altitude was 2.543 and former wildfire forest 2 was $2,531 \mathrm{~m}$ asl. According to Gunarwan (1970), the fire occurred in Mount Talang was classified to crown fire and wide of burnt forest was classified to class A.

The observation was conducted by taking sampling in both locations (former forest fire and natural forest). The soil sampling sized $20 \times 20 \mathrm{~cm}$ was taken in each plot (Figure 1) in depth 0-5 cm, 5-10 cm, 10-15 cm, 15-20 cm. In former forest fire and natural forest, 2 points were observed and resulted in 64 soil seed banks. Similar soil seed bank was separated according to depth and entered into plastic bags with label.
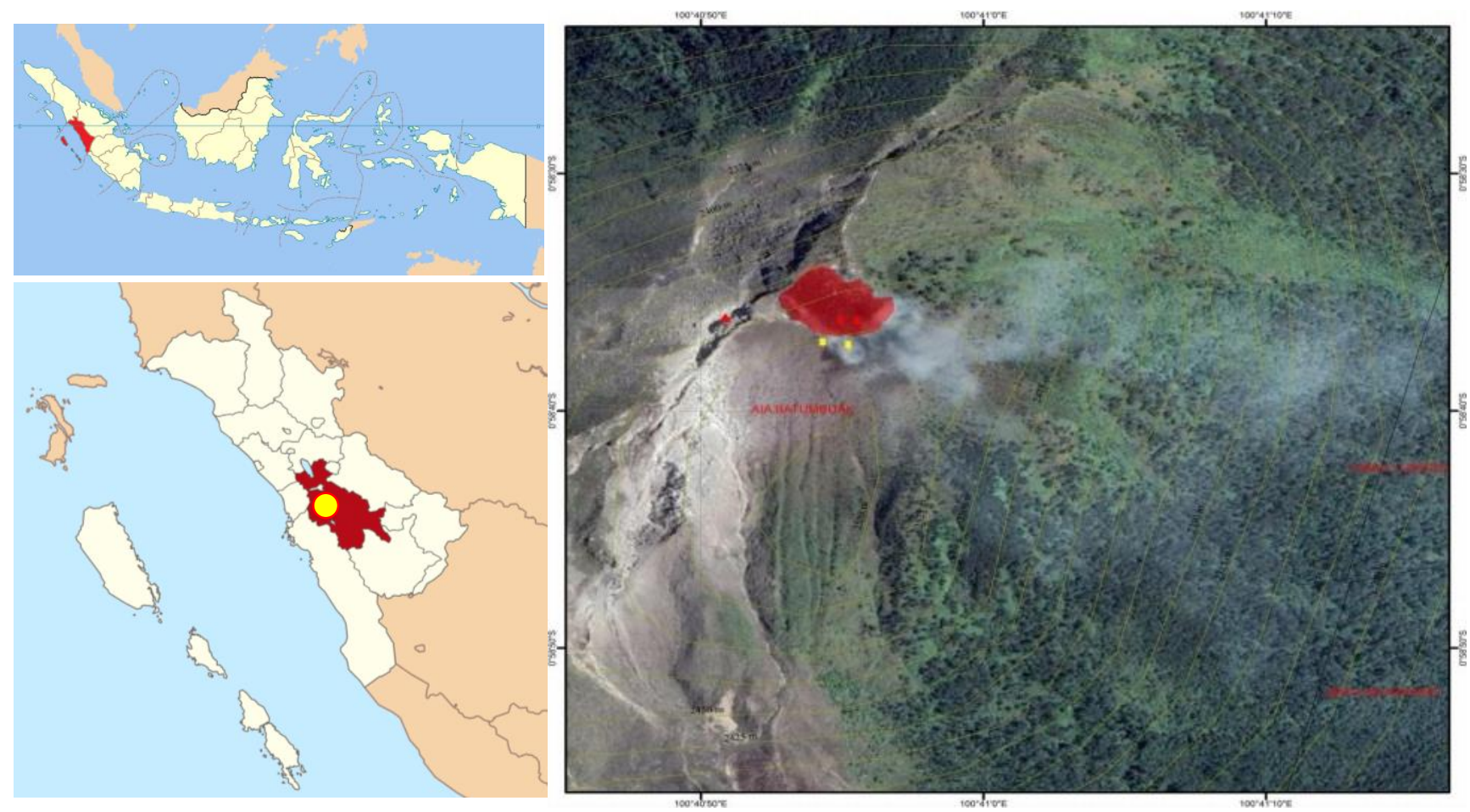

Figure 1. Location of sampling in Mount Talang, West Sumatra, Indonesia 


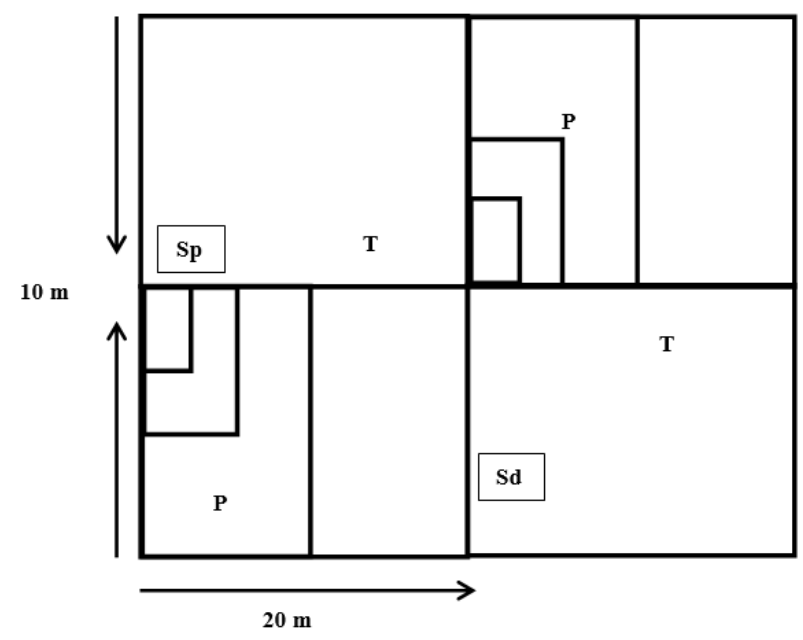

Figure 2. Measuring plot of sampling: $\mathrm{Sp}=\operatorname{Sapling}(5 \mathrm{~m} \times 5 \mathrm{~m})$, $\mathrm{Sd}=$ seedling $(2 \mathrm{~m} \times 2 \mathrm{~m}), \mathrm{T}=$ Tree $(20 \mathrm{~m} \times 20 \mathrm{~m}), \mathrm{P}=$ Pole $(10 \mathrm{~m}$ x 10 m) ( Fachrul 2012)

The samples were carried out to the Laboratory of Seed Technology, Faculty of Agriculture, Andalas University, Indonesia. Before germinating of soil seed bank, 1:1 of soil mixture ratio that was previously roasted to kill the seed weed. The soil was sowed into seedbed sized $35 \times 20 \times 10$ $\mathrm{cm}$ that contained soil seed bank (Siahaan 2014). The humidity of seedbed was maintained by watering every day. The observation and identification of seed banks that grew was conducted every day.

\section{RESULTS AND DISCUSSION}

According to the result of soil seed bank germination that collected from former forest wildfire and natural forest, several plant species were found and were identified in family and species levels. Total 1 family and 14 species of plants were found from natural forest (Table 1 and 2) and 8 species in former forest wildfire (Table 3 and 4). The result showed that for each plot, most of soil seed bank grew in depth $0-5 \mathrm{~cm}$, followed by $5-10 \mathrm{~cm}$ and $10-15 \mathrm{~cm}$. In depth $15-20 \mathrm{~cm}$, there was 1 plant grew, Peperomia pellucida. Ahmad et al. (2017) stated that $P$. pellucida was a wild plant that commonly found in tropical and moist regions. The plant was widely spread in each region of Indonesia and also grew adaptively. The condition caused it could be found in between rocks, forest, field, and others. This plant was classified as herbaceous and could grow up to $20-40 \mathrm{~cm}$.

Total of soil seed banks decreased with the increase in soil depth (Table 1). It was mainly because of soil seed bank germination process in each soil layer was different. Azizah (2015) stated that the environmental factors, treatment and also internal factors of seed affected the germination of soil seed banks. The daily environmental condition of soil acclimatization in Mount Talang natural forest to Laboratory such as temperature of watering, sunlight intensity, and humidity significantly affected soil seed bank germination (Hedari et al. 2014). Temperature range of forest was $15.1-9.1^{\circ} \mathrm{C}$.

Seed banks that underwent dormancy spread in soil profile due to disruption. Generally, seed could germinate if water, oxygen, sunlight and appropriate temperature are available. Fenner and Thompson (2005) stated that seeds in soil surface required shorter time to germinate due to it obtained the germination requirements from their environment. Azizah (2015) stated that herbaceous primary plants such as Peperomia pellucida, Asystasia gangetica, Borreria latifolia, Gleicheniaceae, Cyperus (Cyperus iria) commonly found than woody plants such as Swietenia macrophylla and Gahria javanica (Table 1).

In natural forest 2 , total of soil seed banks grew more (9 plant species) than natural forest 1 (Table 2). In natural forest 2, most of soil seed banks grew in depth 0-5 cm (93). In $15-20 \mathrm{~cm}$, the number of plant species grew more (13) than natural forest 1 (2). Total of herbaceous pioneer such as Croton hirtus, Borreria latifolia, Peperomia pellucida grew more than woody pioneer such as Ficus microcarpa. Soil seed banks such as Cyprus sp., C. iria, C. rorundus, and C. kyllingia commonly grew more than other plants. These species had quick enough growth rate than other species. Cyperaceae grew and spread entirely the world and commonly found in opened fields. This plant grew well if water was enough available and could survive in drought. Cyperaceae was classified as adaptive weed and difficult to control.

In former wildfire forest, 6 number of soil seed banks were identified (Table 3). This number is lower than natural forest 1 and 2 . This difference is due to the viability effect of seed bank (Tiebel et al. 2018). Garwood (1989) also stated that loss of seed bank viability due to genetic factors, a physiology response to environmental factors such as sunlight, temperature, water availability, oxygen and chemical factor, germination of process that caused the seeds piled up in deeper layers.

Number of soil seed banks in each plot was different in former fire forest 1 . Mostly soil seed banks grew in depth $0-5 \mathrm{~cm}$ and the number decreased to follow soil depth. Onwuka (2016) stated that upper soil layers were commonly grown by various plants. In germination process, they showed quick succession process, particularly herbaceous pioneer plants. Much sunlight sources and supported by enough water availability, the soil depth $0-5$ $\mathrm{cm}$ was appropriate for plant growth than lower depth.

Dormancy condition of seed in soil also caused the ability of seed banks to grow after fire. Siahaan (2014) explained that the storage of food on seed determined life and its ability to emerge (seedling emergence). This showed that soil seed banks sometimes could germinate and grow in appropriate environmental conditions. The soil seed bank germination also depended on moisture (Peng et al. 2017). It is reported that $20-10 \%$ of the water content could lengthen seed bank age up to 20 years (Savadogo et al. 2016).

The seed growth rate was also influenced by seed dormancy. Dormancy is seed strategy to survive in stress conditions. In this way, the germination could occur later or it occurred in another place. Furthermore, dormancy 
supported soil seed banks to survive perennially in soil and it just germinated and grew in appropriate environment (Hedari et al. 2014; Liu et al. 2016).

In former forest fire 2, 5 plant species were found and total of soil seed banks in this area was lower than natural forest (Table 4). Mostly, the total of soil seed banks found in depth $0-5 \mathrm{~cm}$. The total of soil seed banks was found to decrease with the depth of soil. In $15-20 \mathrm{~cm}$, no soil seed bank grew. It was caused by there was no soil seed bank found at this layer. Slight number of soil seed banks grew in this area due to seed viability conditions that underwent damage from fire effect. Lower number of plant that grew in a plot, it described lower number of soil seed bank (Siahaan 2014). Dau et al. (2018) stated that main source of seed bank was seed bank that grew previously and seeds were spread by wind, water, broken seeds, animal and human.

Many soil seed banks that were found described revealed that a soil seed bank includes total of seeds produced by plants previously minus death seeds and germinating seeds and also the seeds from outside. The seeds were from outside were not considered to determine seed bank size. Several researchers showed that seeds in soil varied between habitats (Kellerman and Rooyen 2007; Gomaa 2012). Agricultural fields that were intensively used, they generally had more seed storage than fields that were just happened (Landova et al. 2010).

Table 1. Family and species that grew in natural forest 1 for each soil depth

\begin{tabular}{|c|c|c|c|c|c|c|c|c|c|c|c|c|c|c|c|c|}
\hline \multirow{4}{*}{ Family/species } & \multicolumn{4}{|c|}{ Seedling plot } & \multicolumn{4}{|c|}{ Sapling plot } & \multicolumn{4}{|c|}{ Pole plot } & \multicolumn{4}{|c|}{ Tree plot } \\
\hline & \multicolumn{16}{|c|}{ Depth (cm) } \\
\hline & $0-5$ & $5-10$ & 10-15 & 15-20 & $0-5$ & $5-10$ & 10-15 & $15-20$ & $0-5$ & $5-10$ & 10-15 & $15-20$ & $0-5$ & $5-10$ & 10-15 & $15-20$ \\
\hline & \multicolumn{4}{|c|}{ Total } & \multicolumn{4}{|c|}{ Total } & \multicolumn{4}{|c|}{ Total } & \multicolumn{4}{|c|}{ Total } \\
\hline Gleicheniaceae & 1 & 2 & - & - & 2 & 1 & - & - & 4 & 2 & - & - & 1 & 1 & - & - \\
\hline Peperomia pellucida & 2 & 1 & 2 & - & 2 & 1 & 2 & - & 3 & 2 & 1 & - & 5 & 2 & 4 & 2 \\
\hline Asystasia gangetica & 2 & 1 & - & - & 5 & 1 & - & - & 4 & 1 & - & - & 1 & 2 & - & - \\
\hline Swietenia macrophylla & - & 1 & - & - & 1 & - & - & - & - & - & - & - & - & 1 & - & - \\
\hline Cyperus iria & 4 & 3 & 1 & - & 2 & 7 & 4 & - & 2 & 3 & - & - & 4 & 1 & - & - \\
\hline Borreria latifolia & 1 & 1 & 2 & - & - & 1 & 1 & - & 1 & 4 & - & - & 1 & - & 1 & - \\
\hline Gahria javanica & 1 & - & - & - & 2 & - & - & - & 1 & 1 & - & - & 1 & - & - & - \\
\hline Total & 11 & 9 & 5 & 0 & 14 & 11 & 7 & 0 & 15 & 13 & 1 & 0 & 13 & 7 & 4 & 2 \\
\hline
\end{tabular}

Table 2. Family and species that grew in natural forest 2 for each soil depth

\begin{tabular}{|c|c|c|c|c|c|c|c|c|c|c|c|c|c|c|c|c|}
\hline \multirow{4}{*}{ Family/species } & \multicolumn{4}{|c|}{ Seedling plot } & \multicolumn{4}{|c|}{ Sapling plot } & \multicolumn{4}{|c|}{ Pole plot } & \multicolumn{4}{|c|}{ Tree plot } \\
\hline & \multicolumn{16}{|c|}{ Depth (cm) } \\
\hline & $0-5$ & $5-10$ & 10-15 & 15-20 & $0-5$ & $5-10$ & 10-15 & $15-20$ & $0-5$ & $5-10$ & 10-15 & 15-20 & $0-5$ & $5-10$ & 10-15 & $15-20$ \\
\hline & \multicolumn{4}{|c|}{ Total } & \multicolumn{4}{|c|}{ Total } & \multicolumn{4}{|c|}{ Total } & \multicolumn{4}{|c|}{ Total } \\
\hline Cyperus kyllingia & 1 & 1 & 3 & - & 1 & 1 & 2 & - & 3 & 5 & - & - & 12 & 28 & - & - \\
\hline Ficus microcarpa & 2 & - & - & - & 4 & - & - & - & 1 & - & - & - & 1 & - & - & - \\
\hline Croton hirtus & 4 & 3 & 1 & - & 3 & - & 1 & - & 1 & 3 & 3 & - & 7 & 4 & - & - \\
\hline Borreria latifolia & 3 & 1 & 6 & - & 1 & 1 & 2 & - & 1 & 3 & 1 & 1 & 2 & - & - & - \\
\hline Alternanthera sessilis & 2 & 1 & 2 & 1 & 1 & 4 & 1 & - & 9 & 2 & 1 & 2 & 1 & 1 & - & - \\
\hline Peperomia pellucida & 7 & 1 & 2 & 2 & - & - & - & - & 1 & 2 & 1 & - & 2 & 1 & - & - \\
\hline Cyperus iria & 2 & - & 1 & - & 1 & 1 & - & - & - & - & - & - & 25 & - & 25 & 4 \\
\hline Fimbristylis mileacea & - & 4 & 1 & 2 & - & - & - & - & 2 & - & - & - & 2 & 1 & - & - \\
\hline Cyperus rotundus & 2 & 5 & 1 & 1 & - & - & 1 & - & 3 & 1 & 1 & - & 2 & - & - & - \\
\hline Total & 23 & 16 & 17 & 6 & 12 & 7 & 7 & 0 & 16 & 16 & 8 & 3 & 42 & 7 & 28 & 4 \\
\hline
\end{tabular}

Table 3. Plant species that grew in former forest wildfire 1 for each soil depth

\begin{tabular}{|c|c|c|c|c|c|c|c|c|c|c|c|c|c|c|c|c|}
\hline \multirow{4}{*}{ Species } & \multicolumn{4}{|c|}{ Seedling plot } & \multicolumn{4}{|c|}{ Sapling plot } & \multicolumn{4}{|c|}{ Pole plot } & \multicolumn{4}{|c|}{ Tree plot } \\
\hline & \multicolumn{16}{|c|}{ Depth $(\mathrm{cm})$} \\
\hline & $\overline{0-5}$ & $5-10$ & $10-15$ & $15-20$ & $0-5$ & $5-10$ & $10-15$ & $15-20$ & $0-5$ & $5-10$ & $10-15$ & $15-20$ & $0-5$ & $5-10$ & $10-15$ & $15-20$ \\
\hline & \multicolumn{4}{|c|}{ Total } & \multicolumn{4}{|c|}{ Total } & \multicolumn{4}{|c|}{ Total } & \multicolumn{4}{|c|}{ Total } \\
\hline Croton hirtus & 2 & 2 & 3 & - & 4 & 2 & 1 & - & - & 2 & 1 & - & 1 & - & - & - \\
\hline Cleome rutidosperma & 2 & 1 & - & 1 & 4 & 1 & - & 1 & 2 & 1 & 10 & - & 3 & - & 2 & - \\
\hline Ficus microcarpa & - & 1 & - & - & 1 & 1 & - & - & - & - & - & - & - & - & - & - \\
\hline Peperomia pellucida & 5 & 1 & 2 & - & - & 2 & - & & 4 & 4 & - & 3 & 6 & - & - & - \\
\hline Alternanthera sessilis & 3 & 2 & 1 & - & 3 & 3 & 1 & - & - & - & 1 & - & 2 & 1 & - & - \\
\hline Cyperus iria & 7 & 1 & 1 & - & 6 & 1 & 1 & - & - & - & 1 & 1 & 1 & 5 & 3 & - \\
\hline Total & 19 & 8 & 7 & 1 & 18 & 10 & 3 & 2 & 6 & 10 & 13 & 4 & 13 & 6 & 5 & 0 \\
\hline
\end{tabular}


Table 4. Plant species that grew in former forest wildfire 2 for each soil depth

\begin{tabular}{|c|c|c|c|c|c|c|c|c|c|c|c|c|c|c|c|c|}
\hline \multirow{4}{*}{ Species } & \multicolumn{4}{|c|}{ Seedling plot } & \multicolumn{4}{|c|}{ Sapling plot } & \multicolumn{4}{|c|}{ Pole plot } & \multicolumn{4}{|c|}{ Tree plot } \\
\hline & \multicolumn{16}{|c|}{ Depth (cm) } \\
\hline & $0-5$ & $5-10$ & 10-15 & $15-20$ & $0-5$ & $5-10$ & 10-15 & $15-20$ & $0-5$ & $5-10$ & 10-15 & $15-20$ & $0-5$ & $5-10$ & 10-15 & $15-20$ \\
\hline & \multicolumn{4}{|c|}{ Total } & \multicolumn{4}{|c|}{ Total } & \multicolumn{4}{|c|}{ Total } & \multicolumn{4}{|c|}{ Total } \\
\hline Croton hirtus & 2 & 1 & 2 & - & 3 & 1 & - & - & 3 & 1 & - & - & 7 & 1 & - & - \\
\hline Ficus microcarpa & - & - & - & - & 1 & - & - & - & 1 & - & - & - & - & - & - & - \\
\hline Cleome gynandra & 1 & 1 & - & - & - & 1 & - & - & 4 & - & - & - & 2 & - & 1 & - \\
\hline Alternanthera sessilis & 2 & - & - & - & - & 1 & 3 & - & 1 & - & 1 & - & 1 & 3 & 1 & - \\
\hline Podocarpus neriifolius & 1 & - & - & - & 1 & - & - & - & - & 1 & - & - & - & - & - & - \\
\hline Total & 6 & 2 & 2 & 0 & 5 & 3 & 3 & 0 & 9 & 2 & 1 & 0 & 10 & 4 & 2 & 0 \\
\hline
\end{tabular}

Seed banks that underwent dormancy spread in soil profile due to disruption that occurred in soil. Generally, the requirements of seed growth were water availability, oxygen, sunlight and appropriate for seed growth (Ghaderi et al. 2010). It caused the seeds that grew in upper soil layer or near to soil surface, they required shorter time to germinate because it obtained the requirements of growth firstly (Fenner and Thompson 2005).

Croton hirtis was a species grew in all plots. This plant was classified into herbaceous plant. Gue et al. (2015) stated that the plant is a member of Euphorbiaceae and could grow wildly. This plant could be found in grass, plantation area, field and forest and it had to stem rigid hairs.

The observation result in natural and post-fire forest showed that the early vegetation of natural forest was similar to post-wildfire forest due to the condition of forest was secondary forest. The temperature and humidity of the location were similar, $15^{\circ} \mathrm{C}-19^{\circ} \mathrm{C}$ and humidity was $68 \%$. The altitude of location was almost similar, $2529 \mathrm{~m}$ asl and $2524 \mathrm{~m}$ asl for natural forest 1 and $2543 \mathrm{~m}$ asl and $2532 \mathrm{~m}$ asl for former wildfire forest.

The vegetation grew after fire was the pioneer plants that played important role in regeneration of natural forest included the forest that underwent the wildfire. Snyman (2005) stated that the seed bank presence in soil could be determined by seeing the new individual regrowth after wildfire occurred. Benvenuti (2003) added that the plant regeneration which appeared after wildfire occurred was determined by seed compatibility of seed bank to grow and develop. The seed storage in secondary forest played important role as seed source for plant colonization process in succession process.

\section{ACKNOWLEDGEMENTS}

The research team would like to thank all participants who helped and supported the research during it was conducted.

\section{REFERENCES}

Ahmad I, Yanuar A, Mulia K, Mu'nim A. 2017. Application of ionic liquid as green solvent for polyphenolics content extraction of Peperomia pellucida (L) Kunth herb. Young Pharm 9 (4): 486-490
Azizah C, Susanto D, Hendra M. 2015. Potensi cadangan biji pada kedalaman tanah 0-15 cm di area yang berbeda pada hutan sekunder di kebun raya unmul Samarinda. Prosiding Seminar Nasional Ilmu dan Teknologi. Universitas Mulawarman, Samarinda, 5 December 2015. [Indonesian]

Bendixsen DP, Hallgren SW, Burton JA. 2016. Ecological succession following forest decline in a xeric oak forest of south-central United States. J Plant Ecol 9 (4): 402-409

Benvenuti S. Soil texture involvement in germination and emergence of buried weed seeds. Agron J 95:191-198

Center of Volcanology and Geological Hazard Mitigation (CVGHM). 2018. Mount Talang. http://www.vsi.esdm.go.id/index.php/gunungapi/data-dasargunungapi/498-g-talang [Indonesian]

Dau JH, Donald AUA, Chukwu O. Seed banks as conservation tool for endangered wild plant species in ecozones of Nigeria. Res For Wildlife Environ 10 (3): 69-78

Fachrul MF. 2012. Metode Sampling Bioekologi. Bumi Aksara, Jakarta. [Indonesia]

Fenner M, Thompson K. 2005. The ecology of seeds. Cambridge University Press, Cambridge.

Garwood NC. 1989. Tropical soils seed banks: A review. Academic Press Inc. San Diego, USA.

Ghaderi FF, Gherekhloo J, Alimagham M. 2010. Influence of environmental factors on seed germination and seedling emergence of yellow sweet clover (Melilotus officinalis). Planta Dahinha 28 (3): 463-469.

Gomaa NH. 2012. Soil seed bank in different habitats of the eastern desert of Egypt. Saudi J Biol Sci 19: 211-220.

Gue A, Toure A, Ipou JI. 2015. Storage dynamics of seeds of Croton hirtus L'Herit (Euphorbiaceae) in crop soils of Central Western Ivory Coast. J Agric Environ Sci 4 (1): 14-20.

Heidari Z, Kamkar B, Sinaki JM. 2014. Influence of temperature on seed germination response of fennol. Adv Plants Agric Res 1 (5): 207213.

Kellerman MJS, Rooyen MWV. 2007. Seasonal variation in soil seed bank size and species composition of selected habitat types in Maputaland, South Africa. Bothalia. 37 (2): 249-258.

Kusmana C, Hikmat A. 2015. The biodiversity of flora in Indonesia. Pengelolaan Sumber Daya Alam dan Lingkungan. 5 (2): 187-198.

Landova M, Hamouzova K, Soukup J, Jursik M, Holec J, Squire GR. 2010. Population density and soil seed bank of weed beet as influenced by crop sequence and soil tillage. Plant Soil Environ 56 (11): 541-549.

Liu Y, Barot S, El-Kassaby YA, Loeuille N. Impact of temperature shifts on the joint evolution of seed dormancy and size. Ecol Evol 7: 2637

Onwuka BM. 2016. Effects of soil temperature on some soil properties and plant growth. Scholarly J Agric Sci 6 (3): 89-93.

Orozco SMJ, Siebe C, Fernandez DFY. 2017. Causes and effects of forest fires in tropical rainforests: A bibliometric approach. Trop Conserv Sci 10: 1-14.

Peng DL, Hu XJ, Yang J, Sun H. 2018. Seed dormancy, germination and soil seed bank of Lamiophlomis rotata and Marmoritis complanatum (Labiatae), two endemic species from Himalaya-Hengduan Mountains. Plant Biosystem 152 (4): 642-648. 
Puspitojati T. 2011. The issues of forest and non-wood definition in relation to the development of NWFP through forest estate. Analisis Kebijakan Kehutanan. 8 (3): 210-227. [Indonesian]

Rahmasari EK. 2011. Komposisi dan struktur vegetasi pada areal hutan bekas terbakar. IPB Press, Bogor. [Indonesian]

Rehulina, Purwoko S, Latifah S. 2014. Composition and stratification of vegetation in the forest education of University of North Sumatra Tongkoh, Karo District, North Sumatra Province. Peronema For Sci 3 (2): $1-5$.

Santos L, Capelo J, Tavares M. 2010. Germination patterns of soil seed banks in relation to fire in Portuguese littoral pine forest vegetation. Fire Ecol 6 (3): 1-15.

Savadogo P, Sanou L, Dayamba SD, Bognounou F, Thiombiano A. 2017. Relationship between soil seed banks and above-ground vegetation along a disturbance gradient in the W National Park trans-boundary biosphere reserve, West Africa. Plant Ecol 10 (2): 349-363.

Siahaan MP, Purba Irmansyah T. 2014. Composition and weed seed bank density at various soil depth of crop planting area at Balai Benih Induk Tanjung Selamat. Agroteknologi 2 (3): 1181-1189. [Indonesian]
Snyman HA. 2005. The effect of fire on the soil seed bank of a semi-arid grassland in South Africa. South African J Bot 71 (1): 53-60.

Spalink D, Drew BT, Pace MC, Zaborsky JG, Starr JR, Cameron KM, Givnish TJ, Systma KJ. 2016. Biogeography of the cosmopolitan sedges (Cyperaceae) and the area-richness correlation in plants. Biogeography 43 (10): 1893-1904.

Statistic of West Sumatra. 2018. West Sumatra in figures. Statistic of Indonesia, Padang. [Indonesian]

Sutarno, Setyawan AD. 2015. Indonesia's biodiversity: The lost and management efforts to ensure the sovereignty of the nation. Pros Sem Nas Masy Biodiv Indon 1 (1): 1-13. [Indonesian]

Syaufina L. 2008. Kebakaran Hutan dan Lahan di Indonesia: Perilaku Api, Penyebab, dan Dampak Kebakaran. Bayumedia Publishing, Malang. [Indonesian]

Tiebel K, Huth F, Wagner S. 2018. Soil seed banks of pioneer tree species in European temperate forest. iForest. 11: 48-57

Welayaturroman, Susilo A, Triastuty H. 2013. Physical Analysis of Gunung Talang - West Sumatra Activity Based on Spectral Characteristics and Estimates of Volcanic Earthquake Hypocenter. Brawijaya Physic Stud J 1 (1): 1-5. [Indonesian] 